\title{
Outcomes and predictors of success of noninvasive ventilation in acute exacerbation of chronic obstructive pulmonary disease Mostafa Shaheen $^{a}$, Rasha G. Daabis ${ }^{a}$, Hend Elsoucy ${ }^{b}$
}

\begin{abstract}
Background Noninvasive ventilation is appropriately used as a first-line treatment of acute exacerbations of chronic obstructive pulmonary disease (AECOPD) in many emergency departments. It has been evaluated in a large number of trials, often with clinically important benefits, but the use of noninvasive positive pressure ventilation remains highly variable across institutions and geographical regions. The aim of the study was first to emphasize the superiority of noninvasive ventilation (NIV) in acute hypercapneic respiratory failure in patients with an AECOPD in comparison with conventional therapy alone and second was to identify the predictors of NIV failure in such patients.
\end{abstract}

Patients and methods A total of 50 patients were randomly allocated into two equal groups: 25 patients subjected to medical and oxygen therapy (group I) and 25 to medical and NIV (group II). All patients were followed until death or discharge.

Results Group II had a success rate (for weaning and discharge) of $76 \%$, whereas in group I, it was $20 \%$ (odds ratio $=0.0789,95 \%$ confidence interval $=0.021-0.302$ and $P<0.001)$. Hospital stay was significantly longer in group I. Complications were significantly higher in group I. Mortality was significantly higher in group I. Improvement of arterial blood gases, respiratory rate, dyspnea scores and hypercarbic encephalopathy was significantly better in noninvasive positive pressure ventilation (NIPPV) group.

\section{Introduction}

Noninvasive ventilation (NIV) is most beneficial for patients presenting with hypercapnic acute respiratory failure (ARF) caused by an exacerbation of COPD [1]. It has been introduced since the 1980s, and since then, its use in the ICUs in patients with acute respiratory acidosis has been increasing and has doubled over a period of 7 years $[2,3]$.

Nevertheless, the failure of NIV failure may be potentially associated with prolonged invasive mechanical ventilation [4] and increased mortality rate, which can reach up to $45 \%$ in nonselected patient populations [2].

The benefits of NIV [in patients with COPD presenting with acute respiratory acidosis (ARF)] has been highly evidence based and is now documented in the scientific literature, with also a high degree of recommendation in different clinical guidelines [5-13].

The benefits of NIV for patients with acute exacerbation of COPD have been proven in many studies, and
Conclusion The addition of NIPPV to standard therapy confers more benefits in patients with AECOPD, with significant reduction of in-hospital mortality, rate of endotracheal intubation, incidence of complications and length of hospital stay compared with standard therapy alone. On the contrary, failure can be predicted by the presence of more comorbidities, signs of severe exacerbation, high BMI, high baseline blood sugar, rapid respiratory rate at admission, abnormal baseline renal functions, high baseline C-reactive protein, high baseline acute physiology and chronic health evaluation II and BAP 65: B=BUN; A=Altered mental status; $\mathrm{P}=$ Pulse rate; 65-age years (BAP 65) scores, severe acidosis before NIV treatment and persistent severe acidosis after $1 \mathrm{~h}$ of treatment.

Egypt J Bronchol 2018 12:329-339

(c) 2018 Egyptian Journal of Bronchology

Egyptian Journal of Bronchology 2018 12:329-339

Keywords: acute exacerbations of chronic obstructive pulmonary disease, acute hypercapnic respiratory failure, NIPPV

Departments of, ${ }^{a}$ Chest Diseases, ${ }^{b}$ Emergency Medicine, Faculty of Medicine, Alexandria University, Alexandria, Egypt

Correspondence to Rasha G. Daabis, MD, Department of Chest Diseases, Faculty of Medicine, Alexandria University, Alazarita, Alkhartoom Square, Egypt. Tel: 203-484-74-26; fax 203-4873076, e-mail: rgdaabis@gmail.com

Received 8 November 2017 Accepted 19 March 2018

whether these benefits apply to all patients groups and in all settings deserves more assessment.

\begin{abstract}
Aim
The objectives of the present study was first to emphasize the superiority of NIV in acute hypercapneic respiratory failure in patients with an acute exacerbations of chronic obstructive pulmonary disease (AECOPD) in comparison with conventional therapy alone. The second purpose was to identify early predictors of NIV failure in same patients and parameters of shifting to invasive ventilation.
\end{abstract}

\section{Patients and methods Patients}

After approval of the local Ethical Committee, the present study was carried out on 50 adult patients

This is an open access journal, and articles are distributed under the terms of the Creative Commons Attribution-NonCommercial-ShareAlike 4.0 License, which allows others to remix, tweak, and build upon the work non-commercially, as long as appropriate credit is given and the new creations are licensed under the identical terms. 
presenting with acute exacerbation of COPD to Gamal Abdelnasser insurance hospital.

Patients were randomly subdivided into two equal groups:

(1) Group I: 25 patients allocated to receive controlled oxygen therapy in addition to medical treatment.

(2) Group II: 25 patients allocated to receive noninvasive positive pressure ventilation (NPPV) plus medical treatment.

\section{Methods}

A written consent was taken from all participants before the beginning of the study according to the hospital's protocol. All patients in the present study were admitted to ICU and subjected to arterial blood gases (ABG) assessment [by GEM premier 3000 analyzer; Instrumental Laboratory, Bedford (UK), Massachusetts (USA)], routine laboratory testing, ECG and chest radiography. All patients were subjected to standard medical treatment: nebulized salbutamol $2.5-5 \mathrm{mg}$, nebulized ipratropium $500 \mu \mathrm{g}$, systemic glucocorticosteroids ( $40 \mathrm{mg}$ prednisolone) and antibiotics if indicated. The first group was offered controlled oxygen therapy with a target saturation of $88-92 \%$ using venturi masks. The provided $\mathrm{FiO}_{2}$ ranged from 24 to $40 \%$. However, in the second group, NIV was provided within the first $60 \mathrm{~min}$ of their arrival. The participants were included according to the inclusion criteria, and others who met the exclusion criteria were excluded. Table 1 shows the NIPPV settings. All patients were started on an inspiratory positive airway pressure (IPAP) of 10 and expiratory positive airway pressure (EPAP) of $5 \mathrm{~cm} \mathrm{H}_{2} \mathrm{O}$ using oronasal mask. The pressures were gradually adjusted by physicians as tolerated based on continuous pulseoximetry, followup ABG, alleviation of patients' dyspnea, decrease in respiratory rate and good patient - ventilator synchrony. Duration of NIV per day was variable from patient to patient according to initial condition and severity of respiratory acidosis and patient response and tolerance. The least duration for those who tolerated and succeeded was $18 \mathrm{~h}$ and longest duration was $20 \mathrm{~h} /$ day. Least duration for those who could not tolerate and failed was $1 \mathrm{~h}$.

Table 1 BiPAP settings in group II $(n=25)$

\begin{tabular}{lccc}
\hline & Minimum-maximum & Mean \pm SD & Median \\
\hline PEEP & $5-10$ & $6.8 \pm 2.1$ & 7 \\
IPAP & $10-20$ & $14.2 \pm 3.9$ & 15 \\
Duration NIV (h/day) & $1-20$ & $15.3 \pm 7.4$ & 19 \\
$\mathrm{FiO}_{2}$ & $21-100$ & $33.8 \pm 25$ & 24 \\
\hline
\end{tabular}

NIV, noninvasive ventilation. PEEP, positive end-expiratory pressure
Regarding the definitions of treatment success or failure, success was defined as the achievement of a clinical and functional condition stable enough to allow patient discharge to the ward in both groups, whereas failure was defined as a sudden or progressive worsening of arterial blood gas tensions, dyspnea, and/or sensory deterioration leading to shift to NIV, intubation or death in group I and intubation or death in group II.

\section{Statistical analysis}

All statistical analyses were performed using PASW software (version 17; SPSS Inc., Chicago, Illinois, USA). All results were considered statistically significant at $P$ less than 0.05 . Quantitative variables were presented as mean $\pm \mathrm{SD}$. Means for parametric variables were compared by Student $t$-test or analysis of variance according to situation. Nonparametric quantitative variables were compared by MannWhitney test and Kruskal-Wallis test according to situation. Qualitative variables were presented as frequencies, and comparisons were made by $\chi^{2}$-test.

\section{Inclusion criteria}

Patients who fulfilled the definition of ARF were included in the present study. An exacerbation of dyspnea lasting less than 2 weeks, signs of respiratory distress, a respiratory rate above 24 breaths/min, an arterial $\mathrm{pH}$ less than 7.35 and greater than 7.25 and $\mathrm{PaCO}_{2}$ greater than 45 $\mathrm{mmHg}$ were the other inclusion criteria.

\section{Exclusion criteria}

Severe co-morbidity, severe respiratory acidosis $\mathrm{pH}$ less than 7.25, life-threatening hypoxemia, agitation/ confusion/severe cognitive impairment [Glasgow coma scale (GCS)] less than or equal to 8, trauma/ facial burns/recent upper airway or facial surgery, fixed upper airway obstruction, copious respiratory secretions, undrained pneumothorax, vomiting, upper gastrointestinal surgery, haemodynamically unstable requiring pressors/inotropes and bowel obstruction were the exclusion criteria.

\section{Measurements}

(1) History parameters: it included age, sex, BMI (none of the oveweighted patients who failed had obesity hypoventilation syndrome by history or previous pulmonology studies), pack-year index, duration of illness, number of non-ICU and ICU hospitalizations with COPD exacerbation, number of previous endotracheal intubation 
(ETI), number of emergency department visits in last month and time since last hospitalization with AECOPD.

(2) Clinical parameters: it included systemic blood pressure, mean arterial blood pressure heart rate, respiratory rate, temperature, visual analog score (VAS), clinical signs of exacerbation severity, acute physiology and chronic health evaluation II (APACHE II) prediction score, BAP 65 score, GCS, ABG, baseline renal function tests, baseline random blood sugar, C-reactive protein (CRP), and complete blood count values.

(3) Follow-up parameters: respiratory rate, VAS, GCS, and ABG levels were followed at 1, 4, 12, 24 , and $48 \mathrm{~h}$ after start of treatment. CRP and total leukocyte count were followed after 24 and $48 \mathrm{~h}$.

(4) Causes of ARF (or precipitating factors of exacerbation): (a) infections, including three subtypes (upper respiratory tract infections, acute bronchitis and pneumonia), (b) noncompliance on medications, (c) pulmonary embolism, (d) cardiac arrhythmias, (e) high-carbohydrate diet, (f) pneumothorax, (g) sedating drugs, and (h) recent exposure to smoke or dust.

(5) Types and number of chronic comorbidities: (a) hypertension, (b) diabetes, (c) chronic kidney disease (CKD), (d) cardiac arrhythmias [atrial fibrillation (AF)], (e) ischemic heart disease (IHD), (f) congestive heart failure, (g) cerebrovascular disease (stroke), (h) hyperthyroidism, (i) hyperthyroidism, (j) atopy or allergic disorder, (k) rheumatological disease, and (1) other chest problems. Number of chronic comorbidities were categorized as follows: none, 1-2 and greater than or equal to 3 comorbidities.

(6) Outcome measures: (a) treatment success or failure, (b) intolerance to NPPV, (c) endotracheal intubation, (d) dyspnea scores, (e) length of stay in hospital or ICU, (f) number and types of treatment complications, and (g) mortality.

\section{Results}

A total of 50 patients were randomly allocated into two equal groups: group I had 25 patients who were subjected to standard treatment (medical and oxygen therapy) and group II had 25 patients who received standard medical treatment plus NPPV. All patients were followed until death or discharge.

Table 2 demonstrates baseline clinical data of all cases included in the study. There were no statistically significant differences between the two groups regarding any of the following baseline clinical parameters.
With NIV, success rate of $76 \%$ was significantly higher than standard treatment group [odds ratio $(\mathrm{OR})=$ $0.0789,95 \%$ confidence interval $(95 \% \mathrm{CI})=$ $0.021-0.302$ and $P<0.001]$. Hospital stay was significantly shorter $(P<0.001)$. Complications were significantly lower $(P<0.001) ; \quad(\mathrm{OR}=5.41, \quad 95 \%$ $\mathrm{CI}=1.017-28.792$ and $P=0.047)$. Mortality was significantly lower $(P=0.034) ; \quad(\mathrm{OR}=5.411, \quad 95 \%$ $\mathrm{CI}=1.017-28.79$ and $P=0.047)$. Tables $13-15$ illustrate summary of the predictors of outcome and mortality in both studies groups.

Tables 3-5 show the associated precipitating factors of exacerbations and respiratory failure in all patients enrolled in the present study.

Tables 6 and 7 show the number of diseases other than AECOPD (associated comorbidities) in patients of both groups and their relation to outcomes.

Table 8 shows that baseline $\mathrm{pH}$ was significantly less acidotic in successful cases of group I, with $P$ value 0.012 . After $1 \mathrm{~h}$ of treatment, there was more significant improvement in acidosis in NIV group than medical group. Along the whole following intervals, there were more significant improvements in $\mathrm{pH}$ in group II than group I. $\mathrm{PaCO}_{2}$ levels were significantly lower in group

Table 2 Distribution of baseline clinical data in studied groups (at admission)

\begin{tabular}{lccc}
\hline Baseline clinical data & Group I $(n=25)$ & Group II $(n=25)$ & $P$ \\
\hline MABP & $100.7 \pm 13.9$ & $100.7 \pm 16.7$ & 0.999 \\
Heart rate & $109.7 \pm 20.3$ & $110.6 \pm 20.6$ & 0.874 \\
Temperature & $37.8 \pm 1.2$ & $37.5 \pm 0.5$ & 0.202 \\
VAS & $100(85-100)$ & $100(85-100)$ & 0.486 \\
Respiratory rate & $38.2 \pm 7.4$ & $37.6 \pm 6.6$ & 0.764 \\
GCS & $14.1 \pm 1.0$ & $13.7 \pm 1.7$ & 0.167 \\
APACHE II & $13(3-31)$ & $12(3-25)$ & 0.698 \\
BAP 65 score & $1.9 \pm 1.2$ & $1.7 \pm 1.3$ & 0.501 \\
TLC & $12.8 \pm 6.9$ & $10.6 \pm 3.1$ & 0.151 \\
CRP & $30(10-470)$ & $37(10-260)$ & 0.892 \\
RBS & $140.2 \pm 24.1$ & $137.8 \pm 21.5$ & 0.859 \\
Urea & $81.1 \pm 47.0$ & $59.1 \pm 48.3$ & 0.097 \\
$\mathrm{Creatinine}$ & $1.2(0.6-4.2)$ & $1.1(0.49-2.7)$ & 0.228 \\
$\mathrm{pH}$ & $7.3 \pm 0.0$ & $7.3 \pm 0.0$ & 0.365 \\
$\mathrm{PaCO}_{2}$ & $66.3 \pm 8.5$ & $66.5 \pm 11.5$ & 0.939 \\
$\mathrm{PaO}_{2}$ & $79.4 \pm 14.2$ & $76.7 \pm 13.1$ & 0.485 \\
$\mathrm{HCO}_{3}$ & $29.0 \pm 3.3$ & $30.6 \pm 4.4$ & 0.173 \\
$\mathrm{SaO}_{2}$ & $93.2 \pm 2.9$ & $93.4 \pm 3.9$ & 0.845 \\
\hline
\end{tabular}

Normally distributed quantitative data were expressed in mean $\pm S D$ and were compared using Student's $t$-test, abnormally distributed data were expressed in median (minimum-maximum) and were compared using Mann-Whitney test. A, altered mental status; APACHE II, acute physiology and chronic health evaluation II; BAP 65, B=BUN greater than $24 \mathrm{mg} / \mathrm{dl}$; CRP, C-reactive protein; GCS, Glasgow coma scale; MABP, mean arterial blood pressure; $P$, Pulse rate greater than $110 / \mathrm{min}$; RBS, random blood sugar; TLC, total leukocyte count; VAS, visual analog score. 
Table 3 Underlying precipitating factors in each group

\begin{tabular}{|c|c|c|c|c|}
\hline $\begin{array}{l}\text { Precipitating factors of } \\
\text { exacerbations }\end{array}$ & $\begin{array}{l}\text { Group I } \\
(n=25) \\
{[n(\%)]}\end{array}$ & $\begin{array}{c}\text { Group II } \\
(n=25) \\
{[n(\%)]}\end{array}$ & $\chi^{2}$ & $P$ \\
\hline Infections & $14(46)$ & $16(64.0)$ & 0.333 & 0.564 \\
\hline URTIs & $4(16.0)$ & $7(28.0)$ & 1.049 & 0.306 \\
\hline Acute bronchitis & $4(16.0)$ & $5(20.0)$ & 0.136 & ${ }^{\mathrm{FE}} P=1.000$ \\
\hline Pneumonia & $6(24.0)$ & $4(16.0)$ & 0500 & 0.480 \\
\hline $\begin{array}{l}\text { Noncompliance on } \\
\text { medications }\end{array}$ & $4(16.0)$ & $3(12.0)$ & 0.166 & ${ }^{\mathrm{FE}} P=1.000$ \\
\hline Pneumothorax & $2(8.0)$ & $1(4.0)$ & 0.355 & ${ }^{\mathrm{FE}} P=1.000$ \\
\hline Arrhythmias & $2(8.0)$ & $2(8.0)$ & 0.000 & ${ }^{\mathrm{FE}} P=1.000$ \\
\hline $\begin{array}{l}\text { High-carbohydrate } \\
\text { diet }\end{array}$ & $2(8.0)$ & $1(4.0)$ & 0.355 & ${ }^{\mathrm{FE}} P=1.000$ \\
\hline $\begin{array}{l}\text { Pulmonary } \\
\text { embolism }\end{array}$ & $0(0.0)$ & $1(4.0)$ & 1.020 & ${ }^{\mathrm{FE}} P=1.000$ \\
\hline $\begin{array}{l}\text { Recent exposure to } \\
\text { smoke or dust }\end{array}$ & $0(0.0)$ & $1(4.0)$ & 1.020 & ${ }^{\mathrm{FE}} P=1.000$ \\
\hline Drugs & $1(4.0)$ & $0(0.0)$ & 1.020 & ${ }^{\mathrm{FE}} P=1.000$ \\
\hline
\end{tabular}

Table 5 Relation between precipitating factors of exacerbations and mortality in each group

\begin{tabular}{|c|c|c|c|c|}
\hline \multirow{2}{*}{$\begin{array}{l}\text { Precipitating factors } \\
\text { of exacerbations }\end{array}$} & \multicolumn{2}{|c|}{ Mortality $[n(\%)]$} & \multirow[t]{2}{*}{$\chi^{2}$} & \multirow[t]{2}{*}{$\mathrm{FE}_{P}$} \\
\hline & $\begin{array}{l}\text { Survived } \\
(n=17)\end{array}$ & $\begin{array}{c}\text { Nonsurvived } \\
\quad(n=8)\end{array}$ & & \\
\hline \multicolumn{5}{|l|}{ Group I } \\
\hline Infections & $9(52.9)$ & $5(62.5)$ & 0.202 & 1.000 \\
\hline URTIs & $4(23.5)$ & $0(0.0)$ & 2.241 & 0.269 \\
\hline Acute bronchitis & $4(23.5)$ & $0(0.0)$ & 2.241 & 0.269 \\
\hline Pneumonia & $1(5.9)$ & $5(62.5)$ & $9.560^{*}$ & $0.006^{*}$ \\
\hline $\begin{array}{l}\text { Noncompliance on } \\
\text { medications }\end{array}$ & $3(17.6)$ & $1(12.5)$ & 0.107 & 1.000 \\
\hline Pneumothorax & $2(11.8)$ & $0(0.0)$ & 1.023 & 1.000 \\
\hline $\begin{array}{l}\text { High-carbohydrate } \\
\text { diet }\end{array}$ & $2(11.8)$ & $0(0.0)$ & 1.023 & 1.000 \\
\hline Sedating drugs & $1(5.9)$ & $0(0.0)$ & 0.490 & 1.000 \\
\hline \multirow[t]{2}{*}{ Arrhythmias } & $0(0.0)$ & $2(25.0)$ & 4.620 & 0.093 \\
\hline & $n=23$ & $n=2$ & & \\
\hline \multicolumn{5}{|l|}{ Group II } \\
\hline Infections & $15(65.2)$ & $1(50.0)$ & 0.185 & 1.000 \\
\hline URTIs & $7(30.4)$ & $0(0.0)$ & 0.845 & 1.000 \\
\hline Acute bronchitis & $5(21.7)$ & $0(0.0)$ & 0.543 & 1.000 \\
\hline Pneumonia & $3(13.0)$ & $1(50.0)$ & 1.870 & 0.300 \\
\hline $\begin{array}{l}\text { Noncompliance on } \\
\text { medications }\end{array}$ & $4(17.4)$ & $1(50.0)$ & 1.223 & 0.367 \\
\hline Pneumothorax & $1(4.3)$ & $0(0.0)$ & 0.091 & 1.000 \\
\hline $\begin{array}{l}\text { Pulmonary } \\
\text { embolism }\end{array}$ & $0(0.0)$ & $1(50.0)$ & 11.979 & 0.080 \\
\hline $\begin{array}{l}\text { High-carbohydrate } \\
\text { diet }\end{array}$ & $1(4.3)$ & $0(0.0)$ & 0.091 & 1.000 \\
\hline $\begin{array}{l}\text { Recent exposure } \\
\text { to smoke or dust }\end{array}$ & $4(17.4)$ & $1(50.0)$ & 1.223 & 0.367 \\
\hline Arrhythmias & $2(8.7)$ & $0(0.0)$ & 0.189 & 1.000 \\
\hline
\end{tabular}

FE, Fisher's exact; group I, standard medical treatment only; group II, noninvasive ventilation+standard medical treatment; URTIs, upper respiratory tract infections. ${ }^{*} P \leq 0.05$, statistically significant.
Table 4 Relation between the precipitating factors and the outcome in both groups

\begin{tabular}{lcccc}
\hline $\begin{array}{l}\text { Precipitating factors of } \\
\text { exacerbations }\end{array}$ & $\begin{array}{c}\text { Failed } \\
(n=20) \\
{[n(\%)]}\end{array}$ & $\begin{array}{c}\text { Success } \\
(n=5) \\
{[n(\%)]}\end{array}$ & $\chi^{2}$ & ${ }^{\mathrm{FE}_{P}}$ \\
\hline $\begin{array}{l}\text { Group I } \\
\quad \text { Infections }\end{array}$ & $\begin{array}{c}12 \\
(60.0)\end{array}$ & $2(40.0)$ & 0.649 & 0.623 \\
$\quad 3(15.0)$ & $1(20.0)$ & 0.074 & 1.000 \\
$\quad \begin{array}{l}\text { Upper respiratory tract } \\
\text { infection }\end{array}$ & $3(15.0)$ & $1(20.0)$ & 0.074 & 1.000 \\
$\quad \begin{array}{l}\text { Acute bronchitis } \\
\text { Pneumonia }\end{array}$ & $6(30.0)$ & $0(0.0)$ & 1.974 & 0.289 \\
$\quad$ Noncompliance on & $1(5.0)$ & $3(60.0)$ & $9.003^{*}$ & $0.016^{*}$ \\
$\begin{array}{l}\text { medications } \\
\quad\end{array}$ & $n=6$ & $n=19$ & & \\
$\begin{array}{l}\text { Group II } \\
\text { Infections }\end{array}$ & $3(50.0)$ & $13(68.4)$ & 0.672 & 0.630 \\
$\quad \begin{array}{l}\text { Upper respiratory tract } \\
\text { infection }\end{array}$ & $0(0.0)$ & $7(36.8)$ & 3.070 & 0.137 \\
$\quad \begin{array}{l}\text { Acute bronchitis } \\
\text { Pneumonia }\end{array}$ & $1(16.7)$ & $4(21.1)$ & 0.055 & 1.000 \\
$\quad$ Noncompliance on & $2(33.3)$ & $2(10.5)$ & 1.765 & 0.234 \\
medications & $1(16.7)$ & $2(10.5)$ & 0.163 & 1.000 \\
$\quad$ Arrhythmias & $1(16.7)$ & $1(5.3)$ & 0.806 & 0.430 \\
\hline
\end{tabular}

FE, Fisher's exact; group I, standard medical treatment only; group II, noninvasive ventilation+standard medical treatment.

Table 6 Distribution of number of comorbidities in studied groups

\begin{tabular}{lcccc}
\hline $\begin{array}{l}\text { No. of } \\
\text { comorbidities }\end{array}$ & $\begin{array}{c}\text { Group I (n=25) } \\
{[n(\%)]}\end{array}$ & $\begin{array}{c}\text { Group II } \\
(n=25)[n(\%)]\end{array}$ & $\chi^{2}$ & $P$ \\
\hline None & $3(12.0)$ & $10(40.0)$ & 5.463 & 0.065 \\
$1-2$ & $14(56.0)$ & $11(44.0)$ & & \\
$\geq 3$ & $8(32.0)$ & $4(16.0)$ & & \\
\hline
\end{tabular}

FE, Fisher's exact; group I, standard medical treatment only; group II, noninvasive ventilation+standard medical treatment

II at all intervals of follow-up. $\mathrm{PaO}_{2}$ and $\mathrm{SaO}_{2}$ values were unreliable, as some patients were on oxygen therapy before enrollment in the study.

Figure 1 shows a flow diagram illustrating the detailed outcome of all cases throughout the study.

Tables 9-12 show that the improvements of respiratory rate and dyspnea score (VAS) were more significant in NIPPV group vs. standard therapy group.

\section{Discussion}

The present study demonstrated that the use of NIPPV in addition to medical therapy in patients with COPD presenting with hypercapnic ARF siginificantly decreases the incidence of orotracheal intubation, the number of complications, hospital mortality, and hospital stay.

Regarding the $\mathrm{ABG}$ parameters in the present study, baseline $\mathrm{pH}$ seems to be the most important single 
predictor of outcome. In medical group I, among patients with $\mathrm{pH}$ range from 7.25 to $7.30,18$ patients showed $100 \%$ failure, $77.8 \%$ total intubation, and $38.9 \%$ mortality, moreover; the

Table 7 Relation between the type of associated comorbidities and the outcome of cases in studied groups

\begin{tabular}{|c|c|c|c|c|}
\hline $\begin{array}{l}\text { Type of co- } \\
\text { morbidity }\end{array}$ & $\begin{array}{l}\text { Failure } \\
(n=20) \\
{[n(\%)]}\end{array}$ & $\begin{array}{c}\text { Success } \\
\quad(n=5) \\
{[n(\%)]}\end{array}$ & $\chi^{2}$ & $\mathrm{FE}_{P}$ \\
\hline \multicolumn{5}{|l|}{ Group I } \\
\hline Hypertension & $13(65.0)$ & $0(0.0)$ & $6.771^{*}$ & $0.015^{*}$ \\
\hline Diabetes & $9(45.0)$ & $1(20.0)$ & 1.042 & 0.615 \\
\hline CKD & $7(35.0)$ & $0(0.0)$ & 2.431 & 0.274 \\
\hline IHD & 7 (35.0) & $0(0.0)$ & 2.431 & 0.274 \\
\hline $\mathrm{CHF}$ & $2(10.0)$ & $0(0.0)$ & 0.543 & 1.000 \\
\hline $\mathrm{AF}$ & $4(20.0)$ & $0(0.0)$ & 1.190 & 0.549 \\
\hline Stoke & $3(15.0)$ & $0(0.0)$ & 0.852 & 1.000 \\
\hline Rheumatological & $1(5.0)$ & $0(0.0)$ & 0.260 & 1.000 \\
\hline Atopy, allergic & $3(15.0)$ & $1(20.0)$ & 0.074 & 1.000 \\
\hline \multirow{2}{*}{$\begin{array}{l}\text { Other chest } \\
\text { problem }\end{array}$} & $2(10.0)$ & $0(0.0)$ & 0.543 & 1.000 \\
\hline & $n=6$ & $n=19$ & & \\
\hline \multicolumn{5}{|l|}{ Group II } \\
\hline Hypertension & 5 (83.3) & $5(26.3)$ & $6.177^{\star}$ & $0.023^{*}$ \\
\hline Diabetes & $4(66.7)$ & $1(5.3)$ & $10.746^{\star}$ & $0.005^{*}$ \\
\hline CKD & $4(66.7)$ & $0(0.0)$ & $15.079^{*}$ & $0.001^{*}$ \\
\hline IHD & $4(66.7)$ & $1(5.3)$ & $10.746^{\star}$ & $0.005^{\star}$ \\
\hline $\mathrm{AF}$ & 2 (33.3) & $0(0.0)$ & 6.884 & 0.050 \\
\hline Hyperthyroidism & $0(0.0)$ & $1(5.3)$ & 0.329 & 1.000 \\
\hline Stoke & $1(16.7)$ & $1(5.3)$ & 0.806 & 0.430 \\
\hline Rheumatological & $0(0.0)$ & $3(15.8)$ & 1.077 & 0.554 \\
\hline Atopy, allergic & $0(0.0)$ & $1(5.3)$ & 0.329 & 1.000 \\
\hline
\end{tabular}

$\mathrm{AF}$, atrial fibrillation; $\mathrm{CHF}$, congestive heart failure; $\mathrm{CKD}$, chronic kidney disease; FE, Fisher's exact; IHD, ischemic heart disease; group I, standard medical treatment only; group II, noninvasive ventilation+standard medical treatment. ${ }^{*} P \leq 0.05$, statistically significant. survived cases showed longer hospital stay and complications. On the contrary, among patients with $\mathrm{pH}$ range from 7.30 to $7.35,28.6 \%$ showed failure, $14.2 \%$ total intubation and $14.2 \%$ mortality.

In NIPPV group (II), patients with $\mathrm{pH}$ ranged from 7.25 to 7.30, (their no. was 12 out of 25 patients included in the group), 7 of these succeeded and 5 of these (41.7\%) failed and intubated. As regards the survival, 2 of these didn't survive (16.7\%) and 10 of them survived.

While patients with $\mathrm{pH}$ ranged from 7.30 to 7.35 in the same group, (13 patients out of 25), all of these succeeded $100 \%$. As regards the survival, all 13 cases have been survived $100 \%$, with one of them only complicated by chest infection.

Table 8 Comparison between baseline and follow-up pH and $\mathrm{PaCO}_{2}$ of successful cases in both groups at different studied periods $(n=24)$

\begin{tabular}{lccc}
\hline & Group I $(n=25)$ & Group II $(n=25)$ & $P$ \\
\hline $\mathrm{pH}$ & & & \\
On admission & $7.33 \pm 0.01$ & $7.31 \pm 0.03$ & $0.012^{*}$ \\
After 1 h & $7.34 \pm 0.01$ & $7.36 \pm 0.03$ & $0.014^{*}$ \\
After 4 h & $7.34 \pm 0.02$ & $7.39 \pm 0.03$ & $0.002^{*}$ \\
After 12 h & $7.35 \pm 0.02$ & $7.39 \pm 0.02$ & $<0.001^{*}$ \\
After 24 h & $7.36 \pm 0.01$ & $7.40 \pm 0.03$ & $0.006^{*}$ \\
After 48 h & $7.37 \pm 0.02$ & $7.41 \pm 0.03$ & $0.003^{*}$ \\
PaCO 2 & & & \\
On admission & $64.6 \pm 1.1$ & $61.4 \pm 7.4$ & 0.085 \\
After 1 h & $61 \pm 3.6$ & $50.9 \pm 6.3$ & $0.002^{*}$ \\
After 4 h & $58.4 \pm 3.8$ & $45.9 \pm 4.5$ & $<0.001^{*}$ \\
After 12 h & $55.8 \pm 4.5$ & $45.3 \pm 3.4$ & $<0.001^{*}$ \\
After 24 h & $51.8 \pm 4.2$ & $42.8 \pm 4.8$ & $0.001^{*}$ \\
After 48 h & $51.4 \pm 7.1$ & $41.1 \pm 3.1$ & $0.030^{*}$ \\
\hline
\end{tabular}

*Statistically significant at $P \leq 0.05$

Figure 1

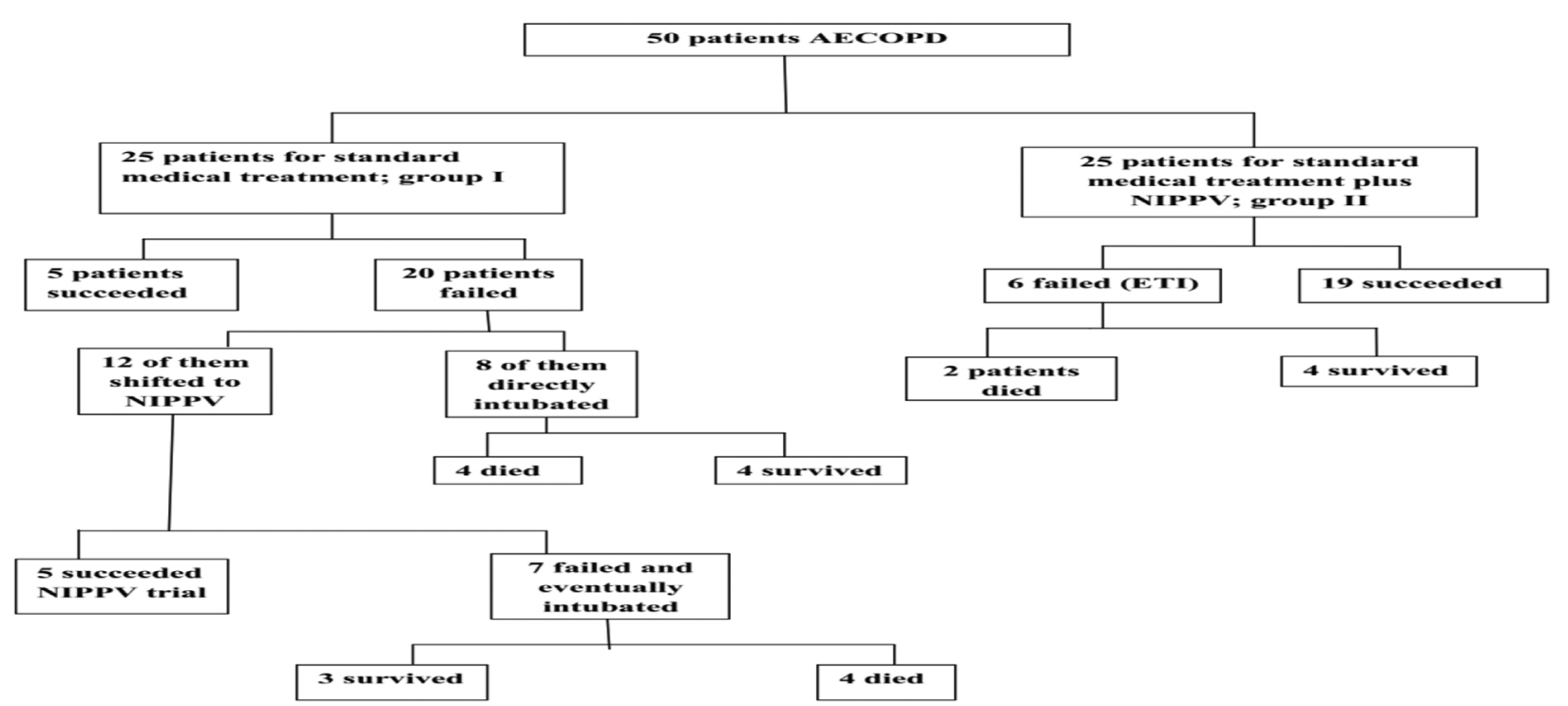

Flow diagram illustrating the detailed outcome of all cases throughout the study 
Table 9 Improvement of respiratory rate in successful cases of group I $(n=5)$ at different studied periods

\begin{tabular}{lcccccc}
\hline & Admission & \multicolumn{5}{c}{ After } \\
\cline { 2 - 7 } & & $1 \mathrm{~h}$ & $4 \mathrm{~h}$ & $12 \mathrm{~h}$ & $24 \mathrm{~h}$ & $48 \mathrm{~h}$ \\
\hline Respiratory rate & $32.6 \pm 3.9$ & $32.8 \pm 6.4$ & $31.6 \pm 5.2$ & $30 \pm 3.1$ & $27.8 \pm 4.2$ & $29.4 \pm 5.9$ \\
$P$ & & 0.880 & 0.230 & $0.049^{*}$ & $0.005^{*}$ & 0.083 \\
\hline
\end{tabular}

$\mathrm{p}_{1}: P$-value for Post Hoc Test (LSD) for ANOVA with repeated measures for comparison between pre admission with each other period.

*Statistically significant at $P \leq 0.05$.

Table 10 Improvement of respiratory rate in successful cases of group II $(n=19)$ at different studied periods

\begin{tabular}{lcccccc}
\hline & Admission & \multicolumn{5}{c}{ After } \\
\cline { 2 - 6 } & & $1 \mathrm{~h}$ & $4 \mathrm{~h}$ & $12 \mathrm{~h}$ & $24 \mathrm{~h}$ & $48 \mathrm{~h}$ \\
\hline Respiratory rate & $35.3 \pm 5.6$ & $31.7 \pm 5.2$ & $29.2 \pm 5.2$ & $27.5 \pm 4.5$ & $26.3 \pm 5$ & $25.2 \pm 4.2$ \\
$P$ & & $<0.001^{*}$ & $<0.001^{*}$ & $<0.001^{*}$ & $<0.001^{*}$ & $<0.001^{*}$ \\
\hline
\end{tabular}

$\mathrm{p}_{1}$ : $P$-value for Post Hoc Test (LSD) for ANOVA with repeated measures for comparison between pre admission with each other period. ${ }^{*}$ Statistically significant at $P \leq 0.05$.

Table 11 Improvement of visual analog score in successful cases of group I $(n=19)$ at different studied periods

\begin{tabular}{|c|c|c|c|c|c|c|}
\hline & \multirow[t]{2}{*}{ Admission } & \multicolumn{5}{|c|}{ After } \\
\hline & & $1 \mathrm{~h}$ & $4 \mathrm{~h}$ & $12 \mathrm{~h}$ & $24 \mathrm{~h}$ & $48 \mathrm{~h}$ \\
\hline VAS & 90 (85-95) & $90(80-90)$ & $80(80-85)$ & 77 (70-85) & $70(70-75)$ & $85(60-90)$ \\
\hline$P$ & & 0.083 & $0.038^{\star}$ & $0.042^{*}$ & $0.038^{\star}$ & 0.068 \\
\hline
\end{tabular}

$\mathrm{p}_{1}$ : $P$-value for Wilcoxon signed ranks test for comparing between pre admission with each other period. VAS, visual analog score. *Statistically significant at $P \leq 0.05$.

Table 12 Improvement of visual analog score in successful cases of group II $(n=19)$ at different studied periods

\begin{tabular}{lccccc}
\hline & Admission & & \multicolumn{2}{c}{ After } \\
\cline { 2 - 5 } & & $1 \mathrm{~h}$ & $4 \mathrm{~h}$ & $12 \mathrm{~h}$ & $24 \mathrm{~h}$ \\
\hline VAS & $100(85-100)$ & $80(60-90)$ & $60(40-85)$ & $50(20-75)$ & $40(15-70)$ \\
$P$ & & $<0.001^{*}$ & $<0.001^{*}$ & $<0.001^{*}$ & $<0.001^{*}$ \\
\hline
\end{tabular}

$\mathrm{p}_{1}$ : $P$-value for Wilcoxon signed ranks test for comparing between pre admission with each other period. ${ }^{\star}$ Statistically significant at $P \leq 0.05$.

The conclusion is that the successful cases among NIV group showed statistically significant higher mean $\mathrm{pH}$ (7.31 \pm 0.03$)$ than that of failed cases $(7.25 \pm 0.01)$; with $P$ value of $<0.001$. The lower the $\mathrm{pH}$ on admission, the higher the failures and mortality.

There was a significant increase in intubation rates with lower $\mathrm{pH}$ values in both groups $(P<0.001)$. These findings were supported by previous randomised studies [13-15]. A low $\mathrm{pH}$ at presentation has shown an association with increased mortality $[15,16]$ and the need for intubation [17] in patients presenting with COPD exacerbations. These results emphasize the importance of baseline severity of acidosis and its important correlation with the prognosis and survival from respiratory failure in patients with COPD. Therefore, early correction of acidosis is a crucial objective in managing those patients [15].

Plant et al. [18] also demonstrated that there is a 22fold higher risk for meeting criteria for intubation in patients with a $\mathrm{pH}$ of 7.35 and a $\mathrm{PaCO}_{2}$ of $6 \mathrm{kPa}$ than those with a $\mathrm{pH}$ of 7.25 and a $\mathrm{PaCO}_{2}$ of $12 \mathrm{kPa}$.
Additionally, the baseline $\mathrm{pH}$ had a reliable predictive effect among several variables [19]. In addition to baseline levels, $\mathrm{pH}$ values after $1 \mathrm{~h}$ of NIV has proved to be a powerful predictor of outcome of NIV as well [20]. In the present study, after $1 \mathrm{~h}$ of NIPPV; the successful cases of group II showed statistically significant higher mean $\mathrm{pH}(7.36 \pm 0.03)$ and lower $\mathrm{PaCO}_{2}$ level $(50.87 \pm 6.29)$ than the failed cases. This means that the severity of acidemia and the degree of hypercapnea after $1 \mathrm{~h}$ of treatment may be predictive factors for the success of NIPPV in COPD cases, and this was in agreement with other studies such Agarwal et al. [21] and Antón et al. [12] who also suggested that if NIPPV does not improve $\mathrm{pH}$ and $\mathrm{RR}$ within the first $2 \mathrm{~h}$, intubation should be considered.

Furthermore, it was notable that the percentage of $\mathrm{pH}$ improvement in successful cases of group II after $1 \mathrm{~h}$ of treatment was by $0.76 \pm 0.23$, whereas in group I was only by $0.11 \pm 0.06$. This came in agreement with a review by Ram et al. [22]. The $\mathrm{pH}$ significantly improved with NPPV in comparison with usual medical care, which was significantly boosted by NPPV. SooHoo et al. [23] also 
Table 13 Predictors of primary outcome for patients of group I

\begin{tabular}{|c|c|c|c|}
\hline & Successful & Failed & $P$ \\
\hline $\mathrm{pH}$ on admission & $7.33 \pm 0.01$ & $\begin{array}{c}7.27 \\
\pm 0.02\end{array}$ & $<0.001^{*}$ \\
\hline $\mathrm{pH}$ after $1 \mathrm{~h}$ & $7.34 \pm 0.01$ & $\begin{array}{r}7.25 \\
\pm 0.04\end{array}$ & $<0.001^{*}$ \\
\hline $\mathrm{PaCO}_{2}$ after $1 \mathrm{~h}$ & $61 \pm 3.5$ & $\begin{array}{c}74.9 \\
\pm 12.1\end{array}$ & $<0.001^{*}$ \\
\hline Baseline GCS & $15 \pm 0$ & $13.9 \pm 1.0$ & $<0.001^{*}$ \\
\hline GCS after $1 \mathrm{~h}$ of treatment & $15 \pm 0$ & $12.5 \pm 1.6$ & $<0.001^{*}$ \\
\hline Baseline heart rate & $88 \pm 6.7$ & $\begin{array}{l}115.1 \\
\pm 18.8\end{array}$ & $<0.001^{*}$ \\
\hline Baseline VAS & $\begin{array}{c}90 \\
(85-95)\end{array}$ & $\begin{array}{c}100 \\
(90-100)\end{array}$ & $<0.001^{*}$ \\
\hline VAS after $1 \mathrm{~h}$ of treatment & $\begin{array}{c}90 \\
(80-90)\end{array}$ & $\begin{array}{c}100 \\
(90-100)\end{array}$ & $<0.001^{*}$ \\
\hline BAP 65 & $0.2 \pm 0.5$ & $2.4 \pm 0.9$ & $<0.001^{*}$ \\
\hline APACHE II score & $4.8 \pm 1.8$ & $15.4 \pm 6$ & $0.001^{*}$ \\
\hline Age & $51.4 \pm 3.3$ & $69.2 \pm 8.4$ & $<0.001^{*}$ \\
\hline \multicolumn{4}{|l|}{ Number of comorbidities } \\
\hline None & $3(60)$ & $0(0)$ & $0.003^{*}$ \\
\hline $1-2$ & $2(40)$ & $12(60)$ & \\
\hline$\geq 3$ & $0(0)$ & $8(40)$ & \\
\hline $\begin{array}{l}\text { Number of ICU } \\
\text { hospitalizations dt AECOPD }\end{array}$ & $0 \pm 0$ & $1.1 \pm 0.8$ & $0.007^{*}$ \\
\hline Abdominal paradox & $0(0)$ & $13(65)$ & $0.015^{*}$ \\
\hline Pack-year index & $18 \pm 27.6$ & $\begin{array}{c}48.1 \\
\pm 18.7\end{array}$ & $0.025^{*}$ \\
\hline RBS & $\begin{array}{l}140.2 \\
\pm 24.9\end{array}$ & $\begin{array}{c}281 \\
\pm 152.9\end{array}$ & $0.032^{*}$ \\
\hline \multicolumn{4}{|l|}{ Sex } \\
\hline Male & $2(40)$ & $18(90)$ & $0.038^{*}$ \\
\hline Female & $3(60)$ & $2(10)$ & \\
\hline
\end{tabular}

Qualitative data were described using number and percentage and compared using $\chi^{2}$-test or Fisher's exact test. Normally quantitative data were expressed in mean \pm SD and compared using Student's $t$-test, and abnormally distributed data were expressed in median (minimum-maximum) and compared using Mann-Whitney test. AECOPD, acute exacerbations of chronic obstructive pulmonary disease; APACHE II, acute physiology and chronic health evaluation II; GCS, Glasgow coma scale; RBS, random blood sugar; VAS, visual analog score. ${ }^{*} P \leq 0.05$, statistically significant.

demonstrated that lack of improvement in respiratory acidosis and respiratory rates during the first few hours of NIV carried a higher likelihood of NIV failure. Confalonieri et al. [24] who studied more than 1000 patients with COPD concluded that a $\mathrm{pH}$ less than 7.25 after $1 \mathrm{~h}$ of NIV use was associated with an increased risk of NIV failure, with even more failure risk when the $\mathrm{pH}$ levels were less than 7.25 on admission [24]. Hence, application of NIV in patients with a $\mathrm{pH}$ less than 7.25 outside well-equiped settings was not recommended [25].

Thus, $\mathrm{pH}$ seems to be a very important variable in predicting failure of medical or NPPV, however; there is much debate what is the correct cutoff value to choose. In the present study, cutoff point of baseline
Table 14 Predictors of primary outcome for patients of group II

\begin{tabular}{|c|c|c|c|}
\hline & Successful & Failed & $P$ \\
\hline $\mathrm{pH}$ on admission & $7.31 \pm 0.03$ & $7.25 \pm 0.01$ & $<0.001^{*}$ \\
\hline $\mathrm{pH}$ after $1 \mathrm{~h}$ & $7.36 \pm 0.03$ & $7.27 \pm 0.03$ & $<0.001^{*}$ \\
\hline $\mathrm{PaCO}_{2}$ on admission & $61.4 \pm 7.4$ & $82.7 \pm 4.8$ & $<0.001^{*}$ \\
\hline $\mathrm{PaCO}_{2}$ after $1 \mathrm{~h}$ & $50.9 \pm 6.3$ & $77 \pm 13.6$ & $0.004^{*}$ \\
\hline Baseline GCS & $14.4 \pm 0.7$ & $10.8 \pm 0.8$ & $<0.001^{*}$ \\
\hline GCS after $1 \mathrm{~h}$ of treatment & $15 \pm 0$ & $10.7 \pm 1.5$ & $0.001^{*}$ \\
\hline Baseline VAS & $\begin{array}{c}100 \\
(85-100)\end{array}$ & $\begin{array}{c}100 \\
(100-100)\end{array}$ & $<0.041^{*}$ \\
\hline Baseline respiratory rate & $35.3 \pm 5.6$ & $45 \pm 3.4$ & $<0.001^{*}$ \\
\hline VAS after $1 \mathrm{~h}$ of treatment & $\begin{array}{c}80 \\
(60-90)\end{array}$ & $\begin{array}{c}100 \\
(90-100)\end{array}$ & $<0.003^{* *}$ \\
\hline BAP 65 score & $1.2 \pm 0.9$ & $3.3 \pm 0.8$ & $<0.001^{*}$ \\
\hline Pedal edema & $0(0)$ & $6(100)$ & $<0.001^{*}$ \\
\hline APACHE II score & $9.5 \pm 4.2$ & $21.5 \pm 2.4$ & $0.024^{*}$ \\
\hline BMI & $26.8 \pm 2.7$ & $32.0 \pm 2.7$ & $<0.001^{*}$ \\
\hline \multicolumn{4}{|l|}{ Number of comorbidities } \\
\hline None & $10(52.6)$ & $0(0)$ & $<0.001^{*}$ \\
\hline $1-2$ & $9(47.4)$ & $2(33.3)$ & \\
\hline$\geq 3$ & $0(0)$ & $4(66.7)$ & \\
\hline \multicolumn{4}{|l|}{ Type of comorbidities } \\
\hline CKD & $0(0)$ & $4(66.7)$ & $0.001^{*}$ \\
\hline Diabetes & $1(5.3)$ & $4(66.7)$ & $0.005^{*}$ \\
\hline IHD & $1(5.3)$ & $4(66.7)$ & $0.005^{\star}$ \\
\hline Hypertension & $5(26.3)$ & 5 (83.3) & $0.023^{*}$ \\
\hline $\begin{array}{l}\text { Number of ICU } \\
\text { hospitalizations dt AECOPD }\end{array}$ & $0.3 \pm 0.5$ & $1.3 \pm 0.8$ & $0.004^{*}$ \\
\hline Abdominal paradox & $5(26.3)$ & $5(83.8)$ & $0.023^{*}$ \\
\hline Pack-year index & $30.8 \pm 14.2$ & $53.3 \pm 19.9$ & $0.026^{*}$ \\
\hline RBS & $\begin{array}{l}137.4 \\
\pm 21.5\end{array}$ & $\begin{array}{l}456.8 \\
\pm 82.5\end{array}$ & $<0.001^{*}$ \\
\hline Central cyanosis & $0(0)$ & $3(50)$ & $0.009^{*}$ \\
\hline TLC & $9.8 \pm 2.1$ & $13 \pm 2.6$ & $0.014^{*}$ \\
\hline CRP & $55.6 \pm 69.9$ & $\begin{array}{l}126.2 \\
\pm 67.6\end{array}$ & $0.014^{*}$ \\
\hline
\end{tabular}

Qualitative data were described using number and percentage and was compared using $\chi^{2}$-test or Fisher's exact test. Normally quantitative data were expressed in mean \pm SD and was compared using Student's $t$-test, and abnormally distributed data were expressed in median (minimum-maximum) and were compared using Mann-Whitney test. AECOPD, acute exacerbations of chronic obstructive pulmonary disease; APACHE II, acute physiology and chronic health evaluation II; CKD, chronic kidney disease; CRP, C-reactive protein; GCS, Glasgow coma scale; $I H D$, ischemic heart disease; RBS, random blood sugar; TLC, total leukocyte count; VAS, visual analog score. ${ }^{*} P \leq 0.05$, statistically significant.

$\mathrm{pH}$ as a predictor of treatment failure in group I was found by ROC curve to be less than or equal to 7.30 (area under the curve: 0.980; 95\% CI: 0.828-0.999, $P<0.001)$. Cutoff point of baseline $\mathrm{pH}$ in group II was obtained as less than or equal to 7.26 (area under the curve: 0.9473 ; 95\% CI: 0.778-0.997, $P<0.001)$.

This came in line with the BTS guidelines 2008 [26] which stated that NIV should be considered in all patients with an AECOPD in whom a respiratory acidosis $(\mathrm{pH} \geq 7.26<7.35)$ resists maximum standard medical treatment on controlled oxygen therapy for no 
Table 15 Predictors of mortality on univariate analysis of patients in both studied groups

\begin{tabular}{lccc}
\hline & Survivors & Nonsurvivors & $P$ \\
\hline Group I & & & \\
GCS & $14.7 \pm 0.6$ & $13 \pm 0.8$ & $<0.001^{*}$ \\
APACHE II score & $10.9 \pm 6.1$ & $18.4 \pm 6.1$ & $<0.001^{*}$ \\
BAP 65 & $1.5 \pm 1.1$ & $2.8 \pm 1$ & $<0.001^{*}$ \\
Heart rate & $101.6 \pm 15.7$ & $126.9 \pm 18.7$ & $0.002^{*}$ \\
Abdominal paradox & $5(29.4)$ & $8(100)$ & $0.002^{*}$ \\
RBS & $181.9 \pm 75.4$ & $403.5 \pm 155$ & $0.004^{*}$ \\
Pneumonia & $1(5.9)$ & $5(62.5)$ & $0.006^{*}$ \\
TLC & $10.4 \pm 5.8$ & $18 \pm 7.4$ & $0.008^{*}$ \\
Pedal edema & $3(17.6)$ & $6(75)$ & $0.010^{*}$ \\
Stroke & $0(0)$ & $3(37.5)$ & $0.024^{*}$ \\
VAS & $100(85-100)$ & $100(100-100)$ & $0.038^{*}$ \\
Group II & & & \\
BAP 65 & $1.5 \pm 1.1$ & $4 \pm 0$ & $<0.001^{*}$ \\
GCS & $13.9 \pm 1.4$ & $10 \pm 0$ & $<0.001^{*}$ \\
Urea & $48.2 \pm 31.4$ & $184.5 \pm 6.4$ & $<0.001^{*}$ \\
pH & $7.30 \pm 0.03$ & $7.26 \pm 0.01$ & $0.002^{*}$ \\
RBS & $189.4 \pm 119$ & $498 \pm 144.3$ & $0.002^{*}$ \\
AF & $0(0)$ & $2(100)$ & $0.003^{*}$ \\
Central cyanosis & $1(4.3)$ & $2(100)$ & $0.010^{*}$ \\
PaCO (mmHg) & $64.9 \pm 10.3$ & $85.5 \pm 6.4$ & $0.011^{*}$ \\
CKD & $2(8.7)$ & $2(100)$ & $0.020^{*}$ \\
Comorbidities & & & \\
None & $10(43.5)$ & $0(0)$ & $0.021^{*}$ \\
1-2 & $11(47.8)$ & $0(0)$ & \\
$\geq 3$ & $2(8.7)$ & $2(100)$ & \\
APACHE II score & $11.5 \pm 6$ & $22 \pm 1.4$ & $0.024^{*}$ \\
Creatinine & $1.1(0.5-2.7)$ & $2.4(2.3-2.5)$ & $0.045^{*}$ \\
Pedal edema & $4(17.4)$ & $2(100)$ & $0.050^{*}$ \\
\hline
\end{tabular}

Qualitative data were described using number and percentage and was compared using $\chi^{2}$-test or Fisher's exact test. Normally quantitative data were expressed in mean $\pm S D$ and were compared using Student's $t$-test, and abnormally distributed data were expressed in median (minimum-maximum) and were compared using Mann-Whitney test. AECOPD, acute exacerbations of chronic obstructive pulmonary disease; APACHE II, acute physiology and chronic health evaluation II; CKD, chronic kidney disease; CRP, C-reactive protein; GCS, Glasgow coma scale; IHD, ischemic heart disease; RBS, random blood sugar; TLC, total leukocyte count; VAS, visual analog score. *Statistically significant at $P \leq 0.05$.

more than $1 \mathrm{~h}$. Although some RCTs show evidence for the efficacy of NIV in patients with COPD with a $\mathrm{pH}$ less than 7.26 [27]. However, NIV treatment failure and intubation are more common in these patients. Moreover they need more intensive monitoring and a lower threshold for intubation [25].

Regarding the comorbidities, it was notable that there was a direct relationship between the increase in comorbidities and the probability of treatment failure in both groups, with $P$ value of 0.003 in group I and of less than 0.001 in group II. A large cross-sectional study performed in the USA has shown that, among other variables, more comorbid conditions were independent risk factors for in-hospital mortality [28].
In NIPPV group, $83.3 \%$ of failed cases had hypertention $(P=0.023), \quad 66.7 \%$ had diabetes $(P=0.005), 66.7 \%$ had $\mathrm{CKD}(P=0.001)$, and $66.7 \%$ had evidence of IHD $(P=0.005)$.

Systemic inflammation is part of COPD pathogensis, which is also related to hypertension and is correlated with higher Medical Research Council dyspnea scores, declined ability for physical activity [29] and airflow obstruction [30].

Moreover in diabetes, there is peripheral airways affection and impaired compliance [31]. The outcomes of COPD are deteriorated by diabetes as it affects a number of parameters; such as shortening time to first hospitalization, increasing hospitalization time and risk of death during exacerbations, increasing Medical Research Council dyspnea scores, and reducing six-minute walking distance [29]. Diabetes negatively affects 5 -year mortality in patients with COPD $[32,36]$. Uncontrolled hyperglycemia in most diabetic patients in the present study played a major role in the adverse outcomes. Random blood sugar was significantly higher in failed cases in both studied groups. Specific details about patients with hyperglycemia treated with NIV are scarce. However, a minute study suggested that 'late failure', defined by falling gas exchange that occurred repeatedly in patients, showed an increased blood sugar initially [37]. A larger but retrospective review of a mingled population of random patients with COPD noted prolonged hospital stays and high levels of death in patients presenting with random blood glucose of greater than $7 \mathrm{mmol} / 1$. Pretherapy hyperglycemia is a freelance predictor of a worse outcome [29,38-42]. More recently, in a relatively small study, Chakrabarti et al. [43] discovered that hyperglycemia, even when detected at only one time point, linked to the eventual result irrespective of the diagnosis of diabetes, utilization of insulin or use of corticosteroid per mouth before. In general, the level of hyperglycemia noted was moderate, but it may still represent the considerable physiological stress connected to diminishing gas exchange and declining lung mechanics, often associated with pulmonary infection. Some patients had radiological clue of pneumonia, but this did not illustrate the existence of hyperglycemia in most patients nor did it foretell NIV failure [43,44]. Strict glycaemic dominance has its supporters $[45,46]$, but precise prospective studies will be indispensable before this policy can be counseled in the managment of patients with primary chest illnesses managed with NIV [43]. 
Regarding CKD, declined normal renal functional reserve was caused by the arterial rigidity and endothelial dysfunction was caused by COPD [47]. Detrioration of renal functional reserve in patients with COPD is associated with more severe airway obstruction and inflammation [47]. Patients with COPD have around double the incidence of acute renal failure, and triple the prevalence of diagnosed chronic renal failure than age-matched and sexmatched controls $[47,48]$.

COPD and IHD share smoking as a common major risk factor. Chronic sustained inflammation and coagulopathy are the traits of both diseases. Elevated CRP level is the key mediator of this sustained inflammation in COPD, and it maintains bronchial constriction and increases the risk for coronary disease $[36,49]$.

In group II, it was notable that all nonsurvived cases had CKD $(P=0.020)$ and $\operatorname{AF}(P=0.003)$, which were the only comorbidities associated with significant relation to mortality in NIV group. AF and COPD are often coexist [50]. AF is itself a known risk factor for stroke and systemic embolism, which may be the causes of death in such cases. The Dyspnea, Eosinopenia, Consolidation, Acidemia and AF (DECAF) score was introduced by Steer et al. [51] as a predictor of mortality in hospitalized patients with COPD exacerbations [51,52]. The score comprises five predictors: dyspnea, eosinopenia, consolidation, acidemia, and AF. AF (on admission ECG) was scored as 1 point in DECAF score. Using the model, the higher the score the higher the mortality rate. High score of 3-6 points indicated in-hospital mortality of $34.6 \%$ [51].

Regarding the respiratory rate, it was significantly more on admission in the patients who failed NIPPV $(P<0.001)$. This means that the baseline respiratory rate could possibly be used as a predictor of success or failure of NIV in cases of AECOPD [53,54]. An initial high respiratory rate and its decrease after $1 \mathrm{~h}$ of NIV have been shown to be correlated with successful NIV outcomes in patients with COPD. From the present study results, the cutoff point of baseline respiratory rate to predict the failure in group I was obtained as greater than 33 breaths/min, whereas in group II, it was greater than 41 breaths/min. Singh et al. [55] reported that a respiratory rate of 30-34 and $\geq 35$ breaths/min at admission were demonstrated to lead to NIV failure, with an OR of 1.83 and 2.66, respectively, whereas the ratios increased to 2.67 and 4.95 , respectively, for the same breathing frequency after $2 \mathrm{~h}$ of NIV.
Using the respiratory rate as a follow-up parameter for comparing the efficacy of each type of treatment, there was a significant decrease in respiratory rate at all studied periods $(P<0.001)$ in group II, whereas in group I, a significant improvement appeared only after 12 and $24 \mathrm{~h}$ ( $P=0.049$ and 0.005 , respectively).

As one of the effects of the NIV is decreasing the load on the respiratory muscles, the RR can fall, the associated pulmonary hyperinflation decreases along with the work of breathing and dyspnea improves [56]. Brochard et al. [57] illustrated reductions in respiratory rate and transdiaphragmatic activity with elevation in tidal volume and minute ventilation. Thus NPPV rapidly improves gas exchange and allows respiratory muscle rest, decreasing respiratory muscle activity in respiratory failure; hence, NPPV gives more time for respiratory muscle recovery and for other conventional treatments (bronchodilators, oxygen, corticosteroids, antibiotics, etc.) to act [57].Regarding the breathlessness scores, VAS was used in the present study as a measurement of dyspnea in all patients. It was significantly higher in failed cases of both groups. After $1 \mathrm{~h}$ of starting treatment, failed cases had higher values as well. This suggests that VAS could be a predictor of success or failure before starting treatment and even after the first hour of therapy. On the contrary, by comparison between successful cases in both groups, statistically significant improvement of VAS at 4, 12, 24, and $48 \mathrm{~h}$ was noticed in favor of NIPPV group. This came in agreement with three studies that measured breathlessness scores using three variable methods (Borg score; [58] VAS; [59] and a verbal-rating scale [13]).

Regarding GCS, it was significantly lower in failed cases of group I either on admission or after $1 \mathrm{~h}$ of follow-up. In NIPPV group, GCS was significantly lower in failed cases at admission, $1 \mathrm{~h}$ and $4 \mathrm{~h}$ after follow-up. GCS was also significantly lower in nonsurvived cases in both groups $(P<0.001)$. This came in agreement with most studies and guidelines which excluded patients with disturbed consciousness owing to theoretical concerns about the propability of aspiration and expected nontolerance to NIV [60-62].

Overall, NIV in the present study was associated with reducing the incidence of orotracheal intubation, which asserts the previous studies' results $[5,10,13,59,60,63-65]$.

Complications were also significantly decreased in NIV group (OR=5.41, 95\% CI: $1.017-28.792$ and $P=0.047)$, confirming previous reports $[27,57,58]$. 
Duration spent in ICU and hospital stay were significantly larger in medical group $I$ than in NIPPV, with $P$ less than 0.001 , which came in line with previous studies $[22,66]$. NIV has been shown to be cost-effective in ICU setting, resulting in a better clinical outcome and decreased costs $[67,68,69]$.

In-hospital mortality was considerably less in NIV group $(\mathrm{OR}=5.411,95 \% \quad \mathrm{CI}: 1.017-28.79$ and $P=0.047$ ), confirming previous reports $[22,66]$.

NIV bilevel positive airway pressure (BiPAP), especifically in the early course of the disease, appears to be an influential add-on therapy with the standard treatment for AECOPD. It appears to be a safe, readily applied modality of ventilatory assistance that reduces the need for intubation, the number of complications and in-hospital mortality. It also accelerates recovery, and shortens hospital stay. It ought to be considered for all the patients with AECOPD with respiratory acidosis unless there is a contraindication for its use, such as a severe respiratory acidosis $\mathrm{pH}$ less than 7.25, life-threatening hypoxemia, severe cognitive impairment (GCS) less than or equal to 8 , failure to secure the airway, profuse respiratory secretions or haemodynamic instability. Risk factors related to its failure may be patient related or nonpatient related, and the emergency medicine clinicians ought to remain vigilant while using NIV. Continuous monitoring and reevaluation remains the key to the successful use of this therapy. Further studies on large number of cases and meta-analysis studies are recommended to develop evidence-based recommendations for the predictors of outcome of NIPPV in patients with AECOPD.

\section{Financial support and sponsorship}

Nil.

\section{Conflicts of interest}

There are no conflicts of interest.

\section{References}

1 Nava S, Hill N. Non-invasive ventilation in acute respiratory failure. Lancet 2009; 374:250-259.

2 Esteban A, Ferguson ND, Meade MO, Frutos-Vivar F, Apezteguia C, Brochard L, et al. Evolution of mechanical ventilation in response to clinical research. Am J Respir Crit Care Med 2008; 177:170-177.

3 Girou E, Brun-Buisson C, Taillé S, Lemaire F, Brochard L. Secular trends in nosocomial infections and mortality associated with noninvasive ventilation in patients with exacerbation of COPD and pulmonary edema. JAMA 2003; 290:2985-2991.

4 Demoule A, Girou E, Richard JC, Taillé S, Brochard L. Increased use of noninvasive ventilation in French intensive care units. Intensive Care Med 2006; 32:1747-1755
5 Lilly CM, Zuckerman IH, Badawi O, Riker RR. Benchmark data from more than 240,000 adults that reflect the current practice of critical care in the United States. Chest 2011; 140:1232-1242.

6 Martin TJ, Hovis JD, Costantino JP, Bierman MI, Donahoe MP, Rogers RM, et al. A randomized, prospective evaluation of noninvasive ventilation for acute respiratory failure. Am J Respir Crit Care Med 2000; 161:807-813.

7 Keenan SP, Sinuff T, Burns KE, Muscedere J, Kutsogiannis J, Mehta S, et al. Clinical practice guidelines for the use of noninvasive positivepressure ventilation and noninvasive continuous positive airway pressure in the acute care setting. CMAJ 2011; 183:E195-E214.

8 Chandra D, Stamm JA, Taylor B, Ramos RM, Satterwhite L, Krishnan JA, et al. Outcomes of noninvasive ventilation for acute exacerbations of chronic obstructive pulmonary disease in the United States, 1998-2008. Am J Respir Crit Care Med 2012; 185:152-159.

9 Crimi C, Noto A, Princi P, Esquinas A, Nava S. A European survey of noninvasive ventilation practices. Eur Respir J 2010; 36:362-369.

10 Hess DR. Noninvasive ventilation for acute respiratory failure. Respir Care 2013; 58:950-972.

11 Brochard L, Mancebo J, Wyoscki M, Lofaso F, Conti G, Rauss A, et al. Non-invasive ventilation for acute exacerbations of chronic obstructive pulmonary disease. N Engl J Med 1995; 333:817-822.

12 Fernández-Vivas M, González-Díaz G, Caturla-Such J, Delgado-Vilchez FJ, Serrano-Simón JM, Carrillo-Alcaraz A, et al. Use of non-invasive ventilation in acute respiratory failure. Multicenter study in intensive care units. Med Intensiva 2009; 33:153-160.

13 Antón A, Güell R, Gómez J, Serrano J, Castellano A, Carrasco JL, et al. Predicting the result of noninvasive ventilation in severeacute exacerbations of patients with chronic airflow limitation. Chest 2000; 117:828-833.

14 Plant PK, Owen JL, Elliott MW. Early use of non-invasive ventilation for acute exacerbations of chronic obstructive pulmonary disease on general respiratory wards: a multicentrerandomised controlled trial. Lancet 2000; 355:1931-1935.

15 Ambrosino N, Vagheggini G. Noninvasive positive pressure ventilation in the acute care setting: where are we? Eur Respir J 2008; 31:874-886.

16 Jeffrey AA, Warren PM, Flenley DC. Acute hypercapnic respiratory failure in patients with chronic obstructive lung disease: risk factors and use of guidelines for management. Thorax 1992; 47:34-40.

17 Warren PM, Flenley DC, Millar JS, Avery A. Respiratory failure revisited: acute exacerbations of chronic bronchitis between 1961-68 and 1970-76. Lancet 1980; 1:467-470.

18 Plant PK, Owen JL, Elliott MW. One year period prevalence study of respiratory acidosis in acute exacerbations of COPD: implications for the provision of noninvasive ventilation and oxygen administration. Thorax 2000; 55:550-554.

19 Plant PK, Owen JL, Elliott MW. Noninvasive ventilation in acute exacerbation of chronic obstructive pulmonary disease: long survival and predictors of in-hospital outcome. Thorax 2001; 56:708-712.

20 Ambrosino N, Foglio K, Rubini F, Cilni E, Nava S, Vitaca M. Non-invasive mechanical ventilation in acute respiratory failure due to chronic obstructive pulmonary disease: correlates for success. Thorax 1995; 50:755-757.

21 Quon BS, Gan WQ, Sin DD. Contemporary management of acute exacerbations of COPD: a systematic review and metaanalysis. Chest 2008; 133:756-766.

22 Agarwal R, Gupta R, Aggarwal AN, Gupta D. Noninvasive positive pressure ventilation in acute respiratory failure due to COPD vs. other causes: effectiveness and predictors of failure in a respiratory ICU in North India. Int J Chron Obstruct Pulmon Dis 2008; 3:737-743.

23 Ram FS, Picot J, Lightowler J, Wedzicha JA. Non-invasive positive pressure ventilation for treatment of respiratory failure due to exacerbations of chronic obstructive pulmonary disease. Cochrane Database Syst Rev 2004; 3:CD004104.

24 Soo Hoo GW, Santiago S, Williams AJ. Nasal mechanical ventilation for hypercapnic respiratory failure in chronic obstructive pulmonary disease: determinants of success and failure. Crit Care Med 1994; 22:1253-1261.

25 Confalonieri M, Garuti G, Cattaruzza MS, Osborn JF, Antonelli M, Conti G, et al. A chart of failure risk for noninvasive ventilation in patients with COPD exacerbation. Eur Respir J 2005; 25:348-355.

26 Ozyilmaz E, Ugurlu AO, Nava S. Timing of noninvasive ventilation failure: causes, risk factors, and potential remedies. BMC Pulm Med 2014; 14:19.

27 Roberts CM, Brown JL, Reinhardt AK, Kaul S, Scales K, Mikelsons C, et al. Non-invasive ventilation in chronic obstructive pulmonary disease: management of acute type 2 respiratory failure. Clin Med (Lond) 2008; 8:517-521. 
28 Conti G, Antonelli M, Navalesi P, Rocco M, Bufi M, Spadetta G, Meduri GU Noninvasive versus conventional mechanical ventilation in patients with chronic obstructive pulmonary disease after failure of medical treatment in the ward: a randomized trial. Intensive Care Med 2002; 28:1701-1707.

29 Patil SP, Krishnan JA, Lechtzin N, Diette GB. In-hospital mortality following acute exacerbations of chronic obstructive pulmonary disease. Arch Intern Med 2003; 163:1180-1186.

30 Schonhofer B, Wenzel M, Geibel M, Köhler D. Blood transfusion and lung function in chronically anemic patients with severe chronic obstructive pulmonary disease. Crit Care Med 1998; 26:1824-1828.

31 Miller J, Edwards LD, Agustí A, Bakke P, Calverley PM, Celli B, et al. Evaluation of COPD Longitudinally to Identify Predictive Surrogate Endpoints (ECLIPSE) Investigators Comorbidity, systemic inflammation and outcomes in the ECLIPSE cohort. Respir Med 2013; 107:1376-1384.

32 Goldman MD. Lung dysfunction in diabetes. Diabetes Care 2003 26:1915-1918.

33 Cazzola M, Bettoncelli G, Sessa E, Cricelli C, Biscione G. Prevalence of comorbidities in patients with chronic obstructive pulmonary disease. Respiration 2010; 80:112-119.

34 Fabbri LM, Luppi F, Beghé B, Rabe KF. Complex chronic comorbidities of COPD. Eur Respir J 2008; 31:204-212.

35 Seshasai SR, Kaptoge S, Thompson A, Di Angelantonio E, Gao P, Sawa $\mathrm{N}$, et al. Emerging Risk Factors Collaboration. Diabetes mellitus, fasting glucose, and risk of cause-specific death. N Engl J Med 2011; 364:829-841.

36 Baker EH, Janaway $\mathrm{CH}$, Philips BJ, Brennan AL, Baines DL, Wood DM, et al. Hyperglycaemia is associated with poor outcomes in patients admitted to hospital with acute exacerbations of chronic obstructive pulmonary disease. Thorax 2006; 61:284-289.

37 Young RP, Hopkins RJ, Christmas T, Black PN, Metcalf P, Gamble GD. COPD prevalence is increased in lung cancer, independent of age, sex and smoking history. Eur Respir J 2009; 34:380-386.

38 Moretti M, Cilione C, Tampieri A, Fracchia C, Marchioni A, Nava S. Incidence and causes of non-invasive mechanical ventilation failure after initial success. Thorax 2000; 55:819-825.

39 Capes SE, Hunt D, Malmberg K, Pathak P, Gerstein HC. Stress hyperglycemia and prognosis of stroke in nondiabetic and diabetic patients: a systematic overview. Stroke 2001; 32:2426-2432.

40 Umpierrez GE, Isaacs SD, Bazargan N, You X, Thaler LM, Kitabchi AE. Hyperglycemia: an independent marker of in-hospital mortality in patients with undiagnosed diabetes. J Clin Endocrinol Metab 2002; 87:978-982.

41 Yendamuri S, Fulda GJ, Tinkhoff GH. Admission hyperglycemia as a prognostic indicator in trauma. J Trauma 2003; 55:33-38.

42 Servillo G, Ughi L, Rossano F, Leone D. Noninvasive mask pressure support ventilation in COPD patients [Abstract]. Intensive Care Med 1994; 50:S54

43 Christiansen C, Toft P, Jørgensen HS, Andersen SK, Tønnesen E. Hyperglycaemia and mortality in critically ill patients. A prospective study. Intensive Care Med 2004; 30:1685-1688.

44 Chakrabarti B, Angus RM, Agarwal S, Lane S, Calverley PM. Hyperglycaemia as a predictor of outcome during non-invasive ventilation in decompensated COPD. Thorax 2009; 64:857-862.

45 Pacilli AM, Valentini I, Carbonara P, Marchetti A, Nava S. Determinants of noninvasive ventilation outcomes during an episode of acute hypercapnic respiratory failure in chronic obstructive pulmonary disease: the effects of comorbidities and causes of respiratory failure. Biomed Res Int 2014 2014:976783.

46 Van den Berghe G, Wouters P, Weekers F, Verwaest C, Bruyninckx F, Schetz $\mathrm{M}$, et al. Intensive insulin therapy in the critically ill patients. N Eng $J$ Med 2001; 345:1359-1367.

47 Van den Berghe G, Wilmer A, Hermans G, Meersseman W, Wouters PJ, Milants I, et al. Intensive insulin therapy in the medical ICU. N Engl J Med 2006; 354:449.

48 Mapel DW, Marton JP. Prevalence of renal and hepatobiliary disease, laboratory abnormalities, and potentially toxic medication exposures among persons with COPD. Int J Chron Obstruct Pulmon Dis 2013; 8:127-134.

49 Chen $\mathrm{C}-\mathrm{Y}$, Liao K-M. Chronic obstructive pulmonary disease is associated with risk of chronic kidney disease: a nationwide case-cohort study. Sci Rep 2016; 6:25855.
50 Brekke $\mathrm{PH}$, Omland $\mathrm{T}$, Smith $\mathrm{P}$, Søyseth V. Underdiagnosis of myocardial infarction in COPD - Cardiac Infarction Injury Score (CIIS) in patients hospitalised for COPD exacerbation. Respir Med 2008; 102:1243-1247.

51 Sin DD, Man SF. Why are patients with chronic obstructive pulmonary disease at increased risk of cardiovascular diseases? The potential role of systemic inflammation in chronic obstructive pulmonary disease. Circulation 2003; 107:1514-1519.

52 Steer J, Gibson J, Bourke SC. The DECAF Score: predicting hospital mortality in exacerbations of chronic obstructive pulmonary disease. Thorax 2012; 67:970-976.

53 Echevarria C, Steer J, Heslop-Marshall K, Stenton SC, Hickey PM, Hughes R, et al. Validation of the DECAF score to predict hospital mortality in acute exacerbations of COPD. Thorax 2016; 71:133-140.

54 Chu CM, Chan VL, Lin AW, Wong IW, Leung WS, Lai CK. Readmission rates and life threatening events in COPD survivors treated with noninvasive ventilation for acute hypercapnic respiratory failure. Thorax 2004 59:1020-1025

55 Bhatt SP, Khandelwal P, Nanda S, Stoltzfus JC, Fioravanti GT. Serum magnesium is an independent predictor of frequent readmissions due to acute exacerbation of chronic obstructive pulmonary disease. Respir Med 2008; 102:999-1003.

56 Singh VK, Khanna P, Rao BK, Sharma SC, Gupta R. Outcome predictors for noninvasive positive pressure ventilation in acute respiratory failure. $J$ Assoc Physicians India 2006; 54:361-365.

57 Appendini L, Patessio A, Zanaboni S, Carone M, Gukov B, Donner CF, et al. Physiologic effects of positive end-expiratory pressure and mask pressure support during exacerbations of chronic obstructive pulmonary disease. Am J Respir Crit Care Med 1994; 149:1069-1076.

58 Brochard L, Isabey D, Piquet J, Amaro P, Mancebo J, Messadi AA, et al. Reversal of acute exacerbations of chronic obstructive lung disease by inspiratory assistance with a face mask. N Engl J Med 1990; 323:1523-1530.

59 Avdeev SN, Tret'iakov AV, Grigor'iants RA, Kutsenko MA, Chuchalin AG. Study of the use of noninvasive ventilation of the lungs in acute respiratory insufficiency due exacerbation of chronic obstructive pulmonary disease. Anesteziol Reanimatol 1998; 3:45-51.

60 Bott J, Carroll MP, Conway JH, Keilty SE, Ward EM, Brown AM, et al. Randomised controlled trial of nasal ventilation in acute ventilatory failure due to chronic obstructive airways disease. Lancet 1993; 341:1555-1557.

61 BTS Guideline. Non-invasive ventilation in acute respiratory failure. $\mathrm{Br}$ Thorac Soc Stand Care Comm Thorax 2002; 57:192-211.

62 Taccone P, Hess D, Caironi P, Bigatello LM. Continuous positive airway pressure delivered with a 'helmet': effects on carbon dioxide rebreathing Crit Care Med 2004; 32:2090-2096.

63 Roche N, Zureik M, Soussan D, Neukirch F, Perrotin D, Urgence BSC Predictors of outcomes in COPD exacerbation cases presenting to the emergency department. Eur Respir J 2008; 32:953-961.

64 Kramer N, Meyer TJ, Meharg J, CeCe RD, Hill NS. Randomised, prospective trial of non-invasive positive pressure ventilation in acute respiratory failure. Am J Resp Crit Care Med 1995; 161:1799-1806.

65 Collaborative Research Group of Noninvasive Mechanical Ventilation for Chronic Obstructive Pulmonary Disease. Early use of non-invasive positive pressure ventilation for acute exacerbations of chronic obstructive pulmonary disease: a multicentre randomized controlled trial. Chin Med J (Engl) 2005; 118:2034-2040.

66 Celikel T, Sungur M, Ceyhan B, Karakurt S. Comparison of noninvasive positive pressure ventilation with standard medical therapy in hypercapnic acute respiratory failure. Chest 1998; 114:1636-1642.

67 Keenan SP, Sinuff T, Cook DJ, Hill NS. Which patients with acute exacerbation of chronic obstructive pulmonary disease benefit from noninvasive positive-pressure ventilation? A systematic review of the literature. Ann Intern Med 2003; 138:861-870.

68 Keenan SP, Gregor J, Sibbald WJ. Noninvasive positive pressure ventilation in the setting of severe, acute exacerbation of chronic obstructive pulmonary disease: more effective and less expensive. Crit Care Med 2000; 28:2094-2102.

69 Lindenauer PK, Stefan MS, Shieh MS, Pekow PS, Rothberg MB, Hill NS. Hospital patterns of mechanical ventilation for patients with exacerbations of COPD. Ann Am Thorac Soc 2015; 12:402-409. 